\title{
DEVELOPMENT OF DESIGN PARAMETERS FOR AN INCLINED STEP-GRATE COMPOST VESSEL TO TREAT URBAN SOLID WASTES
}

\author{
B F A Basnayake, D S Fernando and A M Razmy \\ Faculty of Agriculture, University of Perdeniya.
}

There are several methods and systems of managing urban solid wastes. Acrobic systems of inanaging wastes are less expensive and the composition of wastes in most Sri Lankan cities is conducive to compost making since the biodegradable component is high.

The total quantity of organic manter generated in the urban centres if used as compost will still not satisfy the demand for it. These basic problems could be solved by making compost from hiodegradable urban wastes, lacilitang the management of these wastes and also providing organic matter for long awaited sustained and assured agricultural production in Sri Lanka.

The development of a feasible system of compost making was the challenge taken up by the Department of Agricultural Engineering. A series of studies were undertaken to determine some of the major parameters to realise the concept of an inclined step-grate compostmaking vessel.

The studies indicate that $65 \%$ moisture content should be maintained for optimum conditions for compost making. The bulk density increases with time and it is inversely proportional to mass. Within the first 20 days of degradation of mixed wastes, most of the volatile solids react producing largely carbon dioxide and water. The generated heat from this reaction acluates the process of evaporating excess moisture. The reduction in mass and increase in density can be expressed mathematically.

A calculation of heat and mass balances was obtained for a 3-meter pile of wastes. These calculations were based on data obtained from an Enginecring Model. Several of the major parameters such as the retention time, suction, heating and cooling system for moisture control were developed to design a versatile bio-reactor to produce compost for treating wastes acrobically.

Procedings of the Fourth Annual Forestry and Envinoment Symposium 1998 of the Department of Forestry and Emirommental Science, University of Sri Jaye'neardene'pura, Sri Lanka 